\title{
Implementasi Nilai Agama dan Moral pada Anak Usia Dini melalui Urutan Wudhu
}

\author{
SITI MASRUROH \\ Prodi Pendidikan Agama Islam \\ Universitas Buana Perjuangan Karawang \\ Email: siti.masruroh@ubpkarawang.ac.id
}

\begin{abstract}
Early childhood is a child of golden age or referred to as the "Golden Age." This period must receive special and serious attention from all parties. At present, religious and moral education is highly expected by parents. There are fears of an unlimited global communication era. Affect lifestyle and parenting. Therefore, it is necessary to develop the religious and moral intelligence through the practice of worship, one of which is to implement habituation of ablution in the world of education from early to adulthood.
\end{abstract}

Keywords: Implementation, Religious and Moral Values.

\begin{abstract}
Abstrak
Anak usia dini merupakan anak dengan usia keemasan atau disebut sebagai "Golden Age" Masa ini harus mendapat perhatian khusus dan serius dari semua pihak. Saat ini, pendidikan agama dan moral sangat diharapkan oleh para orang tua. Terdapat kekhawatiran era komunikasi global yang tanpa batas akan mempengaruhi pola hidup dan pola asuh. Untuk itu, perlu pengembangan terhadap kecerdasan agama dan moral melalui pengamalan ibadah. Salah satunya adalah mengimplementasikan pembiasaan wudhu di dunia pendidkan mulai sejak dini hingga dewasa.
\end{abstract}

Kata Kunci: Implementasi, Nilai Agama dan Moral.

\section{Pendahuluan}

\begin{abstract}
Salah satu keutamaan Al- Islam bagi umat Islam adalah metode yang komprehensif, dan paripurna, serta konsisten dalam membina mental, melahirkan generasi emas (golden age) melalui proses belajar. Karena dengan menanamkan nilai-nilai agama dan moral akan memudahkan dalam membentuk generasi yang berkarakter. Tujuan pendidikan pada dasarnya adalah membentuk perubahan dari kebodohan menuju masyarakat yang cerdas dan memiliki wawasan untuk membuat perubahan ke arah yang lebih baik.
\end{abstract}

Interaksi antara guru dan siswa menjadi kunci sukses dalam keberhasilan pembelajaran anak usia dini. Teladan yang diberikan oleh guru akan memberikan pengaruh yang sangat besar terhadap perubahan dan perkembangan siswa.

Tingkat pencapaian perkembangan anak usia dini merupakan pertumbuhan dan perkembangan anak yang dapat dicapai pada rentang usia tertentu. Pertumbuhan anak merupakan pertambhan berat dan tinggi badan yang mencerminkan kondisi kesehatan dan gizi yang mengacu pada tertumbuhan yang dipantau menggunkan instrumen yang dikembangkan kementerian kesehatan.

Standar pendidikan anak usia bertujuan menjamin mutu pendidikan dalam rangka memberikan landasan untuk melakukan stimulasi pendidikan dalam membantu pertumbuhan dan perkembangan jasmani dan rohani sesuai dengan tingkat pencapaian perkembangan anak. Mengoptimalkan 
perkembangan anak secara holistik dan integratif, serta mempersiapkan pembentukan sikap, pengetahuan dan keterampilan anak.

Sedangkan standar tingkat pencapaian perkembangan anak usia dini adalah perkembangan anak merupakan integrasi dari perkembangan aspek nilai agama dan moral, fisik motorik, kognitif, bahasa, sosial-emosional serta seni.

Perkembangan merupakan perubahan perilaku yang berkesinambungan dan terintegrasi dari faktor genetik dan lingkungan serta meningkat secara individual baik kuantitatif maupun kualitatif. Pencapaian pertumbuhan dan perkembangan anak yang optimal membutuhkan keterlibatan orang tua dan orang dewasa serta akses layanan pendidikan anak usia dini yang bermutu.

Mutu Pendidikan Anak usia dini dipengaruhi sejauh mana lembaga mampu mengelola pendidikan pendidikan anak usia dini menjadi sarana mengoptimalkan p e $\mathrm{rk}$ e m b a n a n sertam enstimulan perkembangan anak usia dini.

Berbicara masalah implementasi penanaman nilai agama dan moral melalui pengenalan gerakan wudhu, serta manfaat bagi perkembangan anak usia dini, perlu perhatian yang sangat serius dari semua pemerhati pendidikan. Pendidikan Islam sejak dini merupakan konsep yang sangat mendasar mengenalkan cara beribadah yang benar. Mutu produk pendidikan akan dipengaruhi oleh sejauh mana mampu mengelola secara optimal dalam menstimulus perkembangan anak sejak dini.

Dengan ajaran-ajarannya yang lurus, Islam memberikan tanggung jawab kepada kedua orang tua dan guru, baik melalui pendidikan informal, formal maupun nonformal untuk mengarahkan dan mendidik dengan penuh kasih saying dan teladan. Sehingga akan tumbuh dan berkembang secara istiqamah, tumbuh menjadi generasi yang berkarakter dan memiliki akhlak yang baik. Anak pun akan tumbuh menjadi generasi yang tangguh mampu berdiri sendiri, sehingga mereka memiliki tanggung jawab terhadap diri sendiri, penghormatan dan kemuliaan, baik di hadapan manusia dan tentu mendapat kemuliaan di sisi Allah swt.

\section{Pembahasan}

\section{Implementasi Nilai Agama dan Moral}

Tahap implementasi merupakan tahap penerapan suatu sistem supaya dapat dilaksanakan secara optimal.

Nilai agama dan moral meliputi kemampuan mengenal nilai agama yang dianut, mengerjakan ibadah, berperilaku jujur, penolong, sopan, hormat, sportif, menjaga kebersihan diri dan lingkungan, mengetahui hari besar agama, menghormati dan toleran terhadap agama lain. Dalam pelaksanaan kegiatan perkembangan ini perlu adanya pembiasaan yang terus menerus sesuai dengan jadwal yang telah ditentukan.

Kewajiban pendidik adalah menumbuhkan kesadaran dan pemahaman tentang nilainilai agama dan moral sehingga tumbuh kesadaran dan perkembangan yang dilakukan secara terus menerus dengan bimbingan guru.

Adapun dalam memberikan pemahaman nilai agama dan moral harus mampu mengemas metode yang menarik sesuai dengan dunia anak, yaitu dunia bermain. Bermain disini adalah mengemas metode yang sangat menarik. Anak adalah amanat bagi kedua orang tua, baik di rumah maupun di sekolah sebagai permata yang mahal. Apabila diberikan pembelajaran dengan pembiasaan yang baik, maka akan tumbuh pada kebaikan dan apabila dibiasakan dengan keburukan maka akan tumbuh dengan keburukan. Dan untuk memeliharanya adalah dengan mendidik dan memberikan contoh akhlak-akhlak mulia sesuai dengan nilai-nilai agama dan moral.

Para pendidik dan orang tua memiliki tanggung jawab yang besar untuk melahirkan generasi emas yang berpijak pada landasan iman dan mengajarkan dasar -dasar Islam, sehingga semua terintegrasi antara pendidikan informal (orang tua) dan non formal (pendidikan anak usia dini) dan formal, sehingga melahirkan anak yang berpijak pada landasan pendidikan iman yang sempurna dan mendapatkan ridha Allah swt.

Batasan tanggung jawab dan kewajiban orang tua dan pendidik anak usia dini adalah:

Pertama, tanamkan ketundukan dan keimanan kepada Allah Swt. Mengenalkan atas penciptaan akan keberadaan diri, lingkungan dan alam semesta, yaitu dengan cara mengetahui anggota tubuh serta fungsinya sehingga mampu dipahami oleh akal serta perkembangan anak usia dini; 
Kedua, menanamkan perasaan khusyu', taqwa dan 'ubudiyah kepada Allah Swt. Di dalam jiwa anak -anak dengan jalan membukakan mata mereka agar dapat melihat kekuasaan Allah Swt. Di antara metode untuk menanamkan rasa khusyu', dan memperdalam perasaan taqwa di dalam jiwa adalah melatih dan membiasaakan anak untuk melatih indra pendengaran dengan mendengar ayat-ayat al-Qur'an dan kalimat thayyibah, membiasakan bersuci (wudhu) sebelum shalat. Menanamkan nilai- nilai agama seperti ini adalah dilakukan dan dicontohkan sejak dini, jangan menunggu usia dewasa atau baligh.

Kemudian agar anak selalu mengingat dan melaksanakan perintah Allah Swt. harus ditanamkan dalam perasaannya akan kekuasaan Allah Swt sejak dini. Membentengi anak dari perbuatan negatif atau tercela adalah orang tua ataupun guru selalu mengingatkan bahwa manusia apapun yang dilakukan akan dilihat, didengar oleh Allah Swt. Karena manusia selalu bersama Allah Swt.

Pola pendidikan seperti ini telah diarahkan oleh pendidik pertama yaitu, Nabi Muhammad Saw. ketika beliau menjelaskan tentang arti "ihsan", yaitu: "Engkau beribadah kepada Allah, seakan-akan engkau melihat melihat-Nya. Walaupun engkau tidak melihatNya, namun Dia melihatmu" (HR. Bukhari).

Pada dasarnya pendidikan keimanan, ketundukan kepada Allah swt. sebagai salah satu cara menanamkan nilai agama dan moral yang merupakan tanggung jawab para pendidik mulai dari usia dini hingga dewasa.

Ketiga, membiaskan anak berakhlak mulia. Kewajiban orang tua untuk memberikan teladan dan menanamkan akhlak yang mulia, karena anak merupakan titipan yang Allah Swt. berikan sebagai penerus kelanjutan hidup. Ada tanggung jawab besar yang diamanahkan kepada orang tua dan para pendidik untuk mengantarkan mereka memiliki akhlak mulia. Dalam hadits yang diriwayatkan Anas bin Malik, Rasulullah Saw. bersabda: "Muliakanlah anak-anak kalian dan baguskanlah adab mereka".

Serta diriwayatkan dari Ayub bin Musa, dari Ayahnya bahwa Rasulullah Saw. bersabda: "Tidak ada pemberian paling utama yang diberikan ayah kepada anak selain adab yang baik".

$K$ e e $m p$ a $t$, memi I i hkan t empat pendidikan atau lingkungan yang baik.
Islam sebagai agama yang sempurna mengatur semua kehidupan umat manusia terutama bagi umat Islam diatur, mulai dari sebelum pernikahan sampai merawat dan mendampingi anak hingga dewasa. Hal ini merupakan bukti kasih sayang Allah Swt. yang diberikan kepada manusia sebagai khalifah di muka bumi. Menjadi kewajiban orang tua mampu mengarahkan anakanaknya untuk mengantarkan pendidikan bukan hanya menjadi kewajiban orang tua untuk mengikuti ajaran al-Qur'an dan alHadits dan mampu memberikan kenyamanan lingkungan sekolah, lingkungan bermain yang baik, sehingga anak-anak memiliki akhlak yang baik yang kelak menjadi calon-calon pemimpin masa depan yang lebih baik.

Diriwayatkan dari Anas bin Malik r.a., Rasulullah Saw. bersabda: "Seseorang itu akan mengikuti siapa yang dicintainya, dan ia akan mendaptkan apa yang diusahakannya".

Untuk itu, para orang tua dan para pendidik harus mampu menciptakan suasana yang memberikan nilai-nilai hidup yang baik dan terarah, sehingga menjadi umat yang kuat dan teladan di kemudian hari.

\section{Tanggung Jawab Pendidikan Moral}

Maksud dari pendidikan moral merupakan dasar -dasar pembentukan perilaku. Adapun arti moral dari segi etimologi, berasal dari bahasa latin "mores", yaitu jamak dari "mas", yang berarti adat kebiasaan. Dalam kamus bahasa Indonesia, berarti susila atau kesusilaan nilai atau tindakan manusia dengan ide-ide yang umum diterima oleh kelompok masyarakat.

Maka dengan ini, moral merupakan memberikan batasan terhadap aktivitas manusia dengan nilai (ketentuan) baik dan buruk, benar dan salah. Yang menentukan perbuatan baik dan buruk, benar dan salah merupakan adalah tercipta dan diciptakan di lingkungan masyarakat, sedangkan moral Islam sudah jelas berbeda karena adanya bersifat abadi karena ada sumber moral dalam al-Qur'an dan al-Hadits.

Tanggung jawab orang tua dan para pendidik dalam menanamkan nilai-nilai keimanan sejak anak mulai berkembang di usia dini dengan berpijak pada pendidikan yang berlandaskan iman, dan terdidik dengan selalu takut, ingat, bersandar, meminta pertolongan dan berserah diri kepada Allah Swt. 
Banyak contoh ketika anak- anak dijauhkan dari nilai-nilai agama, maka anak itu sulit untuk diarahkan kepada kebaikan, begitu pula dengan dunia pendidikan apabila lembaga pendidikan hanya memberikan pembalajaran tanpa nilai agama yang terjadi ketidaksesuaian antara cita-cita pendidikan untuk menerdaskan anak yang berakhlak mulia.

Adanya hasil pendidikan yang dijauhkan dari agama, maka akan tumbuh manusia apabila yang pasif, maka ia akan mudah putus asa. Sedangkan manusia yang cerdas dan aktif, maka akan tumbuh menjadi insan yang sombong, takabur, menonjolkan kekuasaan di hadapan manusia. Dalam al-Qur'an dijelaskan: "Dan siapakah yang lebih sesat daripada orang yang mengikuti hawa nafsunya dengan tidak mendapat petunjuk dari Allah Swt. sedikitpun" (QS. 28: 50).

Ini membuktikan bahwa pentingnya nilai- nilai moral ditanamkan kepada anakanak agar tetap mendapat petunjuk dan bimbingan al-Qur'an sebagai pedoman yang mengatur kehidupan. Berikut kutipan dalam buku Tarbiyatul Aulad (Abdullah Nasih Ulwan: 177):

Pertama, Peagot, seorang filosof Jerman mengatakan: "Moral tanpa agama adalah kosong ". Kedua, pemimpin India Mahatma Ghandi mengatakan: "Agama dan moral yang luhur adalah satu kesatuan yang luhur adalah satu kesatuan yang tidak dapat dipisahkan, Agama adalah ruh moral, sedangkan moral adalah suasana bagi ruh itu, Dengan kata lain, agama memberikan makan, menumbuhkan, dan membangkitkan moral, seperti halnya air memberikan makan dan menumbuhkan tanaman."

Ketiga, seorang hakim Inggris, Dinang menyatakan, kecamannya terhadap seorang menteri Inggris yang telah mencemarkan hubungan moral: "Tanpa agama, tidak mungkin moral itu akan ada. Dan tanpa moral, tidak mungkin akan tercipta undangundang. Agama adalah satu-satunya sumber yang terpelihara dan dapat membedakn moral baik dan moral buruk. Agamalah yang mengikatkan manusia untuk meneladani yang paling luhur. Dan agamalah yang membatasi egoisme seseorang, menahan kesewenangwenangan instink, kebiasaan dan menahan perasaan rakus yang hidup dan menjadi dasar berdirinya moral". Keempat, Kant seorang filosof kenamaan mengatakan: "Moral itu tidak akan tercipta tanpa ada tiga keyakinan: Keyakinan adanya Tuhan, kekalnya ruh dan adanya perhitungan kematian".

Islam sangat memperhatikan pendidikan anak-anak dari aspek moral. Ini merupakan petunjuk yang sangat berharga dalam dunia pendidikan. Bagi para pemerhati dan praktisi pendidikan harus mampu mengaplikasikan di dunia pendidikan bagaimana cara dan strategi pembelajaran agar nilai -nilai agama dan moral dapat diterapkan di dunia pendidikan.

Ada beberapa hadits yang menjelaskan bagaimana pentingnya menerapkan nilai-nilai agama dan moral. Ibnu Majah meriwayatkan dari Ibnu Abbas r.a., Rasulullah Saw. bersabda: "Muliakanlah anak -anak kalian dan didiklah mereka dengan budi pekerti yang baik".

Abdul Ar-Razzaq, Sa'i bin Mansyur dan lainnya meriwayatkan hadits dari Ali r.a: "Ajarkanlah kebaikan kepada anak-anak kamu dan keluarga kamu dan didiklah mereka dengan budi pekerti yang baik". Rasulullah Saw. diutus ke muka bumi tugas utama nya menyempurnakan akhlak, prilaku dan tabiat.

\section{Implementasi Wudhu bagi Pendidi- kan Anak Usia Dini}

Melihat kompetensi dasar anak usia dini membuktikan masa usia dini merupakan masa keemasan (Golden Age). Adapun Kompetensi yang perlu dikembangkan oleh pemerhati pendidikan anak usia dini adalah sebagai berikut: 


\section{Standar Tingkat Pencapaian Perkembangan Kelompok Usia 3-4 Tahun}

\begin{tabular}{|c|c|}
\hline LINGKUP PERKEMBANGAN & $\begin{array}{l}\text { TINGKAT PENCAPAIAN } \\
\text { PERKEMBANGAN ANAK }\end{array}$ \\
\hline 1. NILAI AGAMA DAN MORAL & $\begin{array}{l}\text { 1. Mengetahui perilaku yang berlawananmeskipun belum selalu dilakukan } \\
\text { seperti pemahaman perilaku baik-buruk, benar-salah, sopan-tidak } \\
\text { sopan } \\
\text { 2. Mengetahui arti kasih dan sayang kepada ciptaan Tuhan } \\
\text { 3. Mulai meniru doa pendek sesuai dengan agamanya }\end{array}$ \\
\hline $\begin{array}{l}\text { 1. FISIK MOTORIK } \\
\text { A. Motorik Kasar }\end{array}$ & $\begin{array}{l}\text { 1. Berlari sambil membawa sesuatu yang ringan } \\
\text { 2. Naik turun tangga atau tempat yang lebih tinggi dengan kaki bergantian } \\
\text { 3. Meniti diatas papan yang cukup lebar } \\
\text { 4. Melompat turun dari ketinggian kurang lebih } 20 \mathrm{~cm} \text { (dibawah tinggi } \\
\text { lutut anak) } \\
\text { 5. Meniru gerakan senam sederhana seperti menirukan (gerakan pohon, } \\
\text { kelinci melompat) } \\
\text { 6. Berdiri dengan satu kaki }\end{array}$ \\
\hline B.Motorik Halus & $\begin{array}{l}\text { 1. Menuang air, pasir, atau biji-bijian kedalam tempat penampung } \\
\text { (mangkuk, ember) } \\
\text { 2. Memasukkan benda kecil kedalam botol (potongan lidi, kerikil, biji- } \\
\text { bijian) } \\
\text { 3. Meronce benda yang cukup besar } \\
\text { 4. Menggunting kertas mengikuti pola garis lurus }\end{array}$ \\
\hline $\begin{array}{l}\text { C. Kesehatan dan perilaku } \\
\text { keselamatan }\end{array}$ & $\begin{array}{l}\text { 1. Berat badan sesuai tingkat usia } \\
\text { 2. Tinggi badan sesuai tingkat usia } \\
\text { 3. Berat badan sesuai dengan standar tinggi badan } \\
\text { 4. Lingkar kepala sesuai tingkat usia } \\
\text { 5. Membersihkan kotoran (ingus) } \\
\text { 6. Menggosok gigi } \\
\text { 7. Memahami arti warna lampu lalu lintas } \\
\text { 8. Mengelap tangan dan muka sendiri } \\
\text { 9. Memahami kalau berjalan disebelah kiri }\end{array}$ \\
\hline $\begin{array}{l}\text { 2. KOGNITIF } \\
\text { A. Belajar dan pemecahan } \\
\text { masalah }\end{array}$ & $\begin{array}{l}\text { 1. Paham bila ada bagian yang hilang dari suatu pola gambar seperti } \\
\text { pada gambar wajah orang matanya tidak ada, dsb } \\
\text { 2. Menyebutkan berbagai macam nama makanan dan rasanya (garam, } \\
\text { gula, cabai) } \\
\text { 3. Menyebutkan berbagai macam kegunaan dari benda } \\
\text { 4. Memahami persamaan antara dua benda } \\
\text { 5. Memahami perbedaan antara dua hal dari jenis yang sama (buah } \\
\text { rambutan dan pisang, antara ayam dan kucing) } \\
\text { 6. Bereksperimen dengan bahan menggunakan cara baru } \\
\text { 7. Mengerjakan tugas sampai selesai } \\
\text { 8. Menjawab apa yang akan terjadi selanjutnya dariberbagai kemungkinan } \\
\text { 9. Menyebutkan bilangan angka } 1 \text { sampai } 10 \\
\text { 10. Mengenal beberapa huruf atau abjad tertentu dari a-z yang } \\
\text { pernah dilihatnya }\end{array}$ \\
\hline B. Berfikir logis & $\begin{array}{l}\text { 1. Menempatkan benda dalam urutan ukuran (paling kecil-paling besar) } \\
\text { 2. Mulai mengikuti pola tepuk tangan } \\
\text { 3. Mengenal konsep banyak dan sedikit } \\
\text { 4. Mengenali alas an mengapa ada sesuatu yang tidak masuk dalam } \\
\text { kelompok tertentu } \\
\text { 5. Menjelaskan model/ karya yang dibuatnya }\end{array}$ \\
\hline C. Berfikir simbolik & $\begin{array}{l}\text { 1. Menyebutkan peran dan tugasnya (missal, koki tugasnya memasak) } \\
\text { 2. Menggambar atau membentuk sesuatu konstruksi yang } \\
\text { mendeskripsikan sesuatu yang spesifik } \\
\text { 3. Melakukan aktifitas bersama teman dengan terencana (bermain } \\
\text { berkelompok dengan memainkan peran tertentu seperti yang telah } \\
\text { direncanakan) }\end{array}$ \\
\hline
\end{tabular}




\begin{tabular}{|c|c|}
\hline LINGKUP PERKEMBANGAN & $\begin{array}{l}\text { TINGKAT PENCAPAIAN } \\
\text { PERKEMBANGAN ANAK }\end{array}$ \\
\hline $\begin{array}{l}\text { 3. BAHASA } \\
\text { A. Memahami bahasa }\end{array}$ & $\begin{array}{l}\text { 1. Pura pura membaca cerita bergambar dalam buku dengan kata-kata } \\
\text { sendiri } \\
\text { 2. Mulai memahami dua perintah yang diberikan bersamaan contoh: ambil } \\
\text { mainan diatas meja lalu berikan pada ibu pengasuh atau pendidik }\end{array}$ \\
\hline B. Mengungkapkan bahasa & $\begin{array}{l}\text { 1. Mulai menyatakan keinginan dengan mengucapkan kalimat sederhana } \\
\text { (6 kata) } \\
\text { 2. Mulai menceritakan pengalaman yang dialami dengan cerita sederhana }\end{array}$ \\
\hline $\begin{array}{l}\text { 4. SOSIAL EMOSIONAL } \\
\text { A. Kesadaran diri }\end{array}$ & $\begin{array}{l}\text { 1. Mengikuti aktifitas dalam suatu kegiatan besar (missal piknik) } \\
\text { 2. Meniru apa yang dilakukan orang dewasa } \\
\text { 3. Bereaksi terhadap hal-hal yang tidak benar (marah bila diganggu) } \\
\text { 4. Mengatakan perasaan secara verbal }\end{array}$ \\
\hline $\begin{array}{l}\text { B. Tanggungjawab untuk diri sendiri } \\
\text { dan orang lain }\end{array}$ & $\begin{array}{l}\text { 1. Mulai biasa melakukan buang air tanpa bantuan } \\
\text { 2. Bersabar menunggu giliran } \\
\text { 3. Mulai menunjukkan sikap toleran sehingga dapat bekerja dalam } \\
\text { kelompok } \\
\text { 4. Mulai menghargai orang lain } \\
\text { 5. Mulai menunjukkan ekspresi penyesalan ketika melakukan kesalahan }\end{array}$ \\
\hline C. Perilaku prososial & $\begin{array}{l}\text { 1. Membangun kerjasama } \\
\text { 2. Memahami adanya perbedaan perasaan (teman takut, saya tidak) } \\
\text { 3. Meminjam dan meminjamkan mainan }\end{array}$ \\
\hline $\begin{array}{l}\text { 5. Seni } \\
\text { A. Anak mampu membedakan antara } \\
\text { bunyi dan suara }\end{array}$ & $\begin{array}{l}\text { 1. Mengenali berbagai macam suara dari kendaraan } \\
\text { 2. Meminta untuk diperdengarkan lagu favorit secara berulang }\end{array}$ \\
\hline $\begin{array}{l}\text { B. Tertarik dengan kegiatan musik, } \\
\text { gerakan orang, hewan maupun } \\
\text { tumbuhan }\end{array}$ & $\begin{array}{l}\text { 1. Mendengarkan atau menyanyikan lagu } \\
\text { 2. Menggerakkan tubuh sesuai irama } \\
\text { 3. Bertepuk tangan sesuai irama music } \\
\text { 4. Meniru aktivitas orang baik secara langsung maupun melalui media } \\
\text { (missal cara minum, cara bicara/ perilaku seperti ibu) } \\
\text { 5. Bertepuk tangan dengan pola yang berirama (misalnya bertepuk } \\
\text { tangan sambil mengikuti irama nyanyian) } \\
\end{array}$ \\
\hline $\begin{array}{l}\text { C. Tertarik dengan kegiatan atau } \\
\text { karya seni }\end{array}$ & $\begin{array}{l}\text { 1. Menggambar dengan menggunakan beragam media (cat air, spidol, } \\
\text { alat menggambar) dan cara (seperti finger, painting, cat air, dll) } \\
\text { 2. Membentuk sesuatu dengan plastisin } \\
\text { 3. Mengamati dan membedakan benda disekitarnya yang diluar rumah }\end{array}$ \\
\hline
\end{tabular}




\section{Indikator Pencapaian Perkembangan Anak Kelompok Usia 4-5tahun}

\begin{tabular}{|c|c|}
\hline $\mathrm{KD}$ & $\begin{array}{c}\text { INDIKATOR PENCAPAIAN } \\
\text { PERKEMBANGAN ANAK USIA DINI }\end{array}$ \\
\hline $\begin{array}{l}2.1 \text { Mempercayai adanya Tuhan melalui } \\
\text { ciptaan-Nya } \\
2.2 \text { Menghargai diri sendiri, orang lain dan } \\
\text { lingkungan sekitar sebagai nrasa syukur } \\
\text { kepada Tuhan }\end{array}$ & $\begin{array}{l}\text { Indikator pencapaian perkembangan anak untuk KD } \\
\text { pada KI Sikap spiritual dan KD pada KI sikap sosial } \\
\text { tidak dirumuskan secara tersendiri. Pembelajaran untuk } \\
\text { mencapai KD-KD ini dilakukan secara tidak langsung, } \\
\text { tetapi melalui pembelajaran untuk mencapai KD- } \\
\text { KD pada KI pengetahuan dan KI ketrampilan, serta } \\
\text { melalui pembiasaan dan keteladanan. Dengan kata lain } \\
\text { sikap positif anak akan terbentuk ketika dia memiliki } \\
\text { pengetahuan dan mewujudkan pengetahuan itu dalam } \\
\text { bentuk hasil karya dan/atau unjuk kerja. Contoh sikap } \\
\text { positif itu adalah perilaku hidup sehat, jujur, tanggung } \\
\text { jwab, peduli, kreatif, kritis, percaya diri, disiplin, mandiri, } \\
\text { mampu bekerja sama, mampu menyesuaikan diri, dan } \\
\text { santun. }\end{array}$ \\
\hline $\begin{array}{l}\text { 2.1 Memiliki perilaku yang mencerminkan } \\
\text { hidup sehat } \\
2.2 \text { Memiliki perilaku yang mencerminkan } \\
\text { sikap ingin tahu } \\
2.3 \text { Memiliki perilaku yang mencerminkan } \\
\text { sikap kreatif } \\
2.4 \text { Memiliki perilaku yang mencerminkan } \\
\text { sikap estetis } \\
2.5 \text { Memiliki perilaku yang mencerminkan } \\
\text { sikap percaya diri } \\
2.6 \text { Memiliki perilaku yang mencerminkan } \\
\text { sikap taat terhadap aturan sehari-hari untuk } \\
\text { melatih kedisiplinan } \\
\text { 2.7 Memiliki perilaku yang mencerminkan } \\
\text { sikap sabar (mau menunggu giliran, mau } \\
\text { mendengar ketika orang lain berbicara) } \\
\text { untuk melatih kedisiplinan } \\
2.8 \text { Memiliki perilaku yang mencerminkan } \\
\text { sikap kemandirian } \\
2.9 \text { Memiliki perilaku yang mencerminkan } \\
\text { sikap peduli dan mau membantu jika } \\
\text { dimintabantuannya } \\
2.10 \text { Memiliki perilaku yang mencerminkan } \\
\text { sikap menghargai dan toleran terhadap } \\
\text { orang lain } \\
\text { 2.11 Memiliki perilaku dapat menyesuaikan diri } \\
2.12 \text { Memiliki perilaku yang mencerminkan } \\
\text { sikap bertanggung jawab } \\
2.13 \text { Memiliki perilaku yang mencerminkan } \\
\text { sikap santun kepada orang tua, pendidik } \\
\text { dan teman }\end{array}$ & $\begin{array}{l}\text { Indikator pencapaian perkembangan anak untuk KD } \\
\text { pada KI sikap spiritual dan KD pada KI sikap sosial } \\
\text { tidak dirumuskan secara tersendiri, pembelajaran } \\
\text { untuk mencapai KD-KD ini dilakukan secara tidak } \\
\text { langsung, tetapi melalui pembelajaran untuk mencapai } \\
\text { KD-KD pada KI pengetahuan dan KI ketrampilan serta } \\
\text { melalui pembiasaan dan keteladanan. Dengan kata lain } \\
\text { sikap positif anak akan terbentuk ketika dia memiliki } \\
\text { pengetahuan dan mewujudkan pengetahuan itu dalam } \\
\text { bentuk hasil karya dan/atau unjuk kerja. Contoh sikap } \\
\text { positif itu adalah perilaku hidup sehat, jujur, tanggung } \\
\text { jawab, peduli, kreatif, kritis, percaya diri, disiplin, mandiri, } \\
\text { mampu bekerja sama, mampu menyesuaikan diri, dan } \\
\text { santun }\end{array}$ \\
\hline $\begin{array}{l}\text { 3.1 Mengenal kegiatan beribadah sehari- } \\
\text { hari } \\
4.1 \text { Melakukan kegiatan beribadah } \\
\text { sehari-hari dengan tuntunan orang } \\
\text { dewasa }\end{array}$ & $\begin{array}{l}\text { - Mulai mengucapkan doa-doa pendek dan melakukan ibadah } \\
\text { sesuai dengan agama yang dianutnya }\end{array}$ \\
\hline $\begin{array}{l}3.2 \text { Mengenal perilaku baik sebagai } \\
\text { cerminan akhlak mulia } \\
\text { 4.2 Menunjukkan perilaku santun sebagai } \\
\text { cerminan akhlak mulia }\end{array}$ & $\begin{array}{l}\text { - Bersikap sopan dan peduli melalui perkataan dan perbuatannya } \\
\text { dengan bimbingan (missal; mengucapkan maaf, permisi, } \\
\text { terima kasih) } \\
\text { - Mulai menunjukkan sikap mau menolong orang tua, pendidik } \\
\text { dan teman }\end{array}$ \\
\hline
\end{tabular}




\begin{tabular}{|c|c|}
\hline KD & $\begin{array}{c}\text { INDIKATOR PENCAPAIAN } \\
\text { PERKEMBANGAN ANAK USIA DINI }\end{array}$ \\
\hline $\begin{array}{l}\text { 3.3 mengenal anggota tubuh, fungsi dan } \\
\text { gerakannya untuk pengembangan } \\
\text { motorik kasar dan motorik halus } \\
4.3 \text { menggunakan anggota tubuh untuk } \\
\text { pengembangan motorik halus }\end{array}$ & 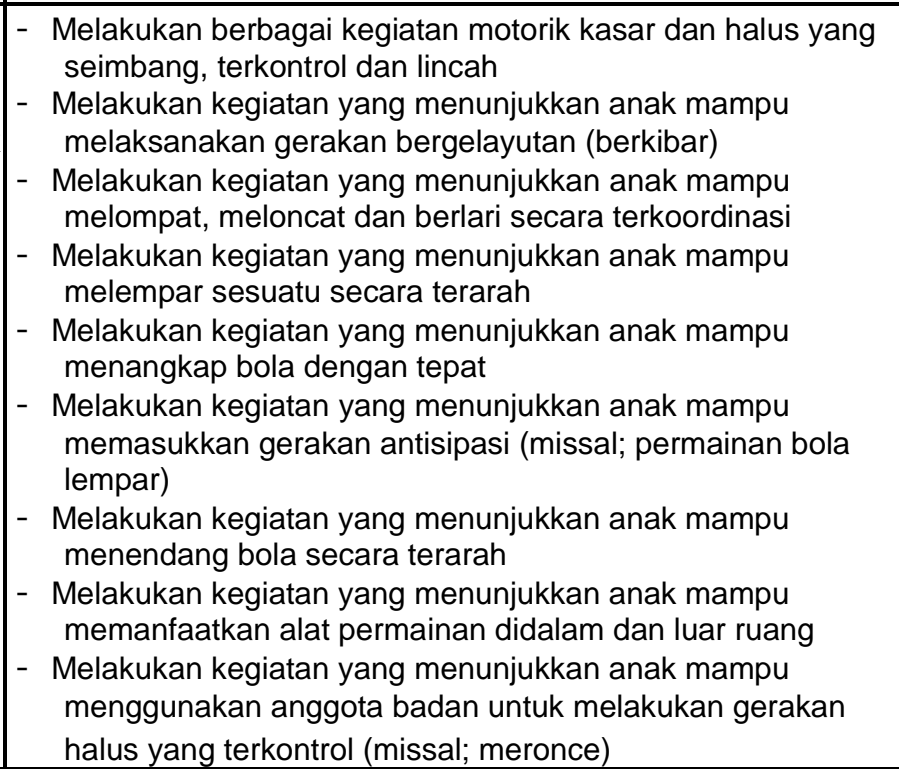 \\
\hline $\begin{array}{l}\text { 3.4 Mengetahui cara hidup sehat } \\
\text { 4.4 Mampu menolong diri sendiri untuk } \\
\text { hidup sehat }\end{array}$ & $\begin{array}{l}\text { - Mulai terbiasa melakukan hidup bersih dan sehat } \\
\text { - Melakukan kegiatan yang menunjukkan anak mampu } \\
\text { mengenali bagian tubuh yang harus dilindungi dan tahu cara } \\
\text { melindungi dari kekerasan, termasuk kekerasan seksual } \\
\text { - Mulai terbiasa mengkonsumsi makanan dan minuman yang } \\
\text { bersih sehat dan bergizi } \\
\text { - Menggunakan toilet tanpa bantuan }\end{array}$ \\
\hline $\begin{array}{l}\text { 3.5 Mengetahui cara memecahkan } \\
\text { masalah sehari-hari dan berperilaku } \\
\text { kreatif } \\
\text { 4.5 Menyelesaikan masalah sehari-hari } \\
\text { secara kreatif }\end{array}$ & $\begin{array}{l}\text { - Mampu memecahkan masalah sederhana yang dihadapi } \\
\text { dibantu oleh orang-orang dewasa } \\
\text { - Melanjutkan kegiatan sampai selesai }\end{array}$ \\
\hline $\begin{array}{l}\text { 3.6. Mengenal benda-benda disekitarnya } \\
\text { (nama, warna, bentuk, ukuran, pola, } \\
\text { sifat, ukuran, tekstur, fungsi dan cirri- } \\
\text { ciri lainnya) } \\
\text { 4.6. Menyampaikan tentang apa dan } \\
\text { bagaimana benda-benda disekitarnya } \\
\text { yang dikenalnya (nama, warna, } \\
\text { bentuk, ukuran, pola, sifat, ukuran, } \\
\text { tekstur, fungsi dan ciri-ciri lainnya) } \\
\text { melalui berbagai hasil karya }\end{array}$ & $\begin{array}{l}\text { - Melakukan kegiatan yang menunjukkan anak mampu } \\
\text { mengenal benda dengan mengelompokkan berbagai benda } \\
\text { berdasarkan ukuran (missal; besar-kecil, panjang -pendek, } \\
\text { tebal-tipis, berat-ringan) } \\
\text { - } \text { Melakukan kegiatan yang menunjukkan anak mampu } \\
\text { mengenal benda dengan mengurutkan benda berdasarkan } \\
\text { ukuran dari yang terpendek sampai yang terpanjang, terkecil- } \\
\text { terbesar } \\
\text { - Melakukan kegiatan yang menunjukkan anak mampu } \\
\text { mengenal benda berdasarkan bentuk, ukuran, warna melalui } \\
\text { kegiatan mengelompokkan } \\
\text { - Melakukan kegiatan yang menunjukkan anak mampu } \\
\text { mengenal konsep besar-kecil, banyak-sedikit, panjang- } \\
\text { pendek, berat-ringan, tinggi-rendah, melalui kegiatan yang } \\
\text { membandingkan }\end{array}$ \\
\hline
\end{tabular}




\begin{tabular}{|c|c|}
\hline $\mathrm{KD}$ & $\begin{array}{c}\text { INDIKATOR PENCAPAIAN } \\
\text { PERKEMBANGAN ANAK USIA DINI }\end{array}$ \\
\hline $\begin{array}{r}\text { 3.7. Mengenal lingkungan sosial } \\
\text { (keluarga, teman, tempat tinggal, } \\
\text { tempat ibadah, budaya, transportasi) } \\
4.7 \text { Menyajikan berbagai karya yang } \\
\text { berhubungan dengan lingkungan } \\
\text { sosial (keluarga, teman, tempat } \\
\text { tinggal, tempat ibadah, budaya, } \\
\text { transportasi) dalam bentuk gambar, } \\
\text { bercerita, bernyanyi dan gerak tubuh }\end{array}$ & 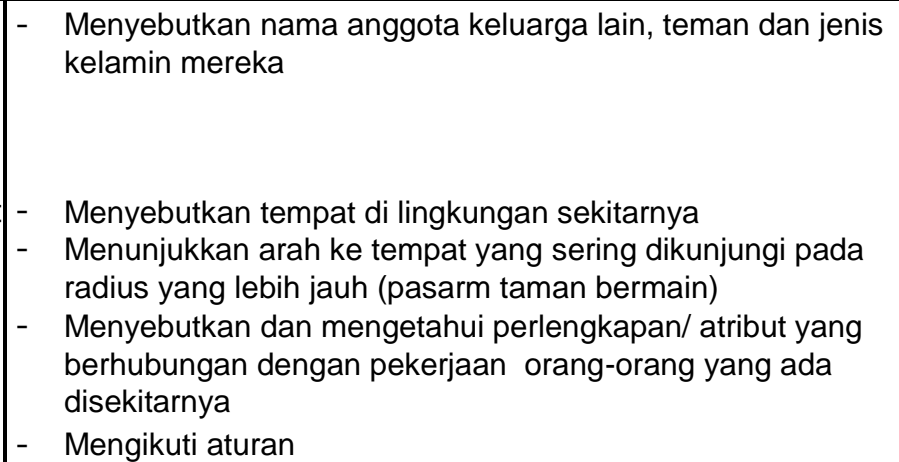 \\
\hline $\begin{array}{l}\text { 3.8. Mengenal lingkungan alam (hewan, } \\
\text { tanaman, cuaca, tanah, air, batu- } \\
\text { batuan dll) } \\
\text { 4.8. Menyajikan berbagai karya yang } \\
\text { berhubungan dengan lingkungan } \\
\text { alam (hewan, tanaman, cuaca, tanah, } \\
\text { air, batu-batuan dII) dalam bentuk } \\
\text { gambar, bercerita, bernyanyi dan } \\
\text { gerak tubuh }\end{array}$ & $\begin{array}{ll}\text { - } & \text { Menunjuk nama dan kegunaan benda-benda alam } \\
\text { - } & \text { Mengungkapkan hasil karya yang dibuat secara sederhana } \\
\text { yang berhubungan dengan benda-benda yang ada di } \\
\text { lingkungan alam } \\
\text { - } \begin{array}{l}\text { Menunjukkan proses pengembangbiakan mahluk hidup } \\
\text { (missal; kupu-kupu, ayam, katak,dll) }\end{array}\end{array}$ \\
\hline $\begin{array}{l}\text { 3.9. Mengenal teknologi sederhana } \\
\text { (peralatan rumah tangga, peralatan } \\
\text { bermain, peralatan pertukangan, dII) } \\
\text { 4.9 Menggunakan teknologi sederhana } \\
\text { untuk menyelesaikan tugas dan } \\
\text { kegiatannya (peralatan rumah } \\
\text { tangga, peralatan bermain, peralatan } \\
\text { pertukangan, dII) }\end{array}$ & $\begin{array}{l}\text { - Menggunakan cara penggunaan benda-benda teknologi } \\
\text { sederhana (misal gunting, sekop, palu, cangkul, pisau, gunting } \\
\text { kuku, sikat gigi, sendok, pembuka tutup botol, spons, roda, } \\
\text { pada kendaraan) } \\
\text { - } \quad \text { Mengenal bahan-bahan pembuatan teknologi sederhana }\end{array}$ \\
\hline $\begin{array}{l}\text { 3.10. Memahami bahasa reseptif } \\
\text { (menyimak dan membaca) } \\
4.10 \text {. Menunjukkan kemampuan } \\
\text { berbahasa reseptif (menyimak dan } \\
\text { membaca) }\end{array}$ & \begin{tabular}{|l} 
- \\
yenceritakan kembali apa yang didengar dengan kosa kata \\
- \\
Melaksanakan perintah sederhana sesuai dengan aturan \\
yang disampaikan (misal; aturan makan bersama)
\end{tabular} \\
\hline $\begin{array}{l}\text { 3.11. Memahami bahasa ekspresif } \\
\text { (mengungkapkan bahasa secara } \\
\text { verbal dan non verbal) } \\
4.11 \text {. Menunjukkan kemampuan } \\
\text { berbahasa ekspresif (mengungkapkan } \\
\text { bahasa secara verbal dan non verbal) }\end{array}$ & $\begin{array}{l}\text { - } \begin{array}{l}\text { Menggunakan kalimat pendek untuk berinteraksi dengan anak } \\
\text { atau orang dewasa untuk menyatakan apa yang dilihat dan } \\
\text { dirasa }\end{array} \\
\text { - } \quad \text { Menceritakan gambar yang ada pada buku } \\
\text { - } \begin{array}{l}\text { Berbicara sesuaidengan kebutuhan (kapan harus bertanya, } \\
\text { berpendapat) } \\
\text { - }\end{array} \\
\text { Bertanya dengan menggunakan lebih dari } 2 \text { kata-kata Tanya } \\
\text { seperti; apa, mengapa, bagaimana, dimana }\end{array}$ \\
\hline $\begin{array}{l}\text { 3.12. Mengenal keaksaraan awal dengan } \\
\text { bermain } \\
4.12 \text {. Menunjukkan kemampuan } \\
\text { keaksaraan awal dalam berbagai } \\
\text { bentuk karya }\end{array}$ & $\begin{array}{l}\text { - } \quad \text { Menulis huruf-huruf yang dicontohkan dengan cara meniru } \\
\text { - } \quad \text { Menceritakan isi buku walaupun tidak sama tulisan dengan } \\
\text { bahasa yang diungkapkan } \\
\text { - } \quad \text { Menghubungkan benda-benda konkret dengan lambing } \\
\text { bilangan 1-10 }\end{array}$ \\
\hline $\begin{array}{l}\text { 3.13. Mengenal emosi diri dan orang lain } \\
\text { 4.13. Menunjukkan reaksi emosi diri } \\
\text { secara wajar }\end{array}$ & $\begin{array}{l}\text { - } \text { Menjalin pertemanan dengan anak lain } \\
\text { - } \quad \text { Mempertahankan haknya untuk melindungi diri dengan } \\
\text { bantuan orang lain missal; memi nta bantuan kepada orang } \\
\text { dewasa }\end{array}$ \\
\hline
\end{tabular}




\begin{tabular}{|c|c|}
\hline $\mathrm{KD}$ & $\begin{array}{c}\text { INDIKATOR PENCAPAIAN } \\
\text { PERKEMBANGAN ANAK USIA DINI }\end{array}$ \\
\hline $\begin{array}{l}\text { 3.14. Mengenali kebutuhan, keinginan } \\
\text { dan minat diri } \\
\text { 4.14. Mengungkapkan kebutuhan, } \\
\text { keinginan dan minat diri dengan cara } \\
\text { yang tepat }\end{array}$ & $\begin{array}{l}\text { - Memilih satu macam dari 2-3 pilihan yang tersedia (missal; } \\
\text { mainan, makananm pakaian) } \\
\text { - Memilih satu dari berbagai kegiatan/ benda yang disediakan }\end{array}$ \\
\hline $\begin{array}{l}\text { 3.15. Mengenal berbagai karya dan } \\
\text { aktifitas seni } \\
\text { 4.15. Menunjukkan karya dan aktifitas } \\
\text { seni dengan menggunakan berbagai } \\
\text { media }\end{array}$ & $\begin{array}{l}\text { - Menghargai penampilan karya seni anak lain (misal dengan } \\
\text { bertepuk tangan dan memuji) } \\
\text { - Menampilkan karya seni sederhana didepan anak atau orang } \\
\text { lain }\end{array}$ \\
\hline
\end{tabular}

\section{Tahapan Pendidikan Anak Usia Dini dalam Islam}

Tahapan yang paling fundamental dalam mendidik anak usia dini yaitu menanamkan keimanan, sesuai dengan usia anak. Tahapan perkembangan anak ini perlu diketahui oleh orang tua dan pendidik perlu adanya pengembangan metode variatif, sehingga mudah diterapkan di setiap tahapan perkembangan anak usia dini. Adapun metode pendidikan anak dalam Islam, yaitu:

\section{Metode Keteladanan}

Dalam metode ini, sangat penting diterapkan pada anak usia dini, dimana usia perkembangan masih masa meniru prilaku orang dewasa. Ketika orang tua atau pendidik memiliki kepedulian terhadap perkembangan anak usia dini, pasti akan berusaha memberikan teladan yang sebaikbaiknya sesuai dengan tuntunan dan ajaran Islam.

Metode keteladanan merupakan metode yang sangat penting akan keberhasilan pendidikan selanjutnya, sehingga mampu memberikan pondasi akan pentingnya moral, spiritual dan kebiasaan. Ketika orang tua dan guru memberikan teladan pentingya wudhu sebagi syarat untuk taat dan patuh kepada Allah Swt. yaitu shalat maka anak akan mudah meniru dan akan membekas sampai dewas. Ketika anak mulai beranjak remaja dan dewasa maka akan mudah memberikan pengertian pentingnya wudhu dan shalat. Rasulullah Saw. diutus sebagai teladan, seperti dijelaskan dalam QS. 33: 21, yaitu: "Sesungguhnya telah ada dalam (diri) Rasulullah Saw. itu suri tauladan yang baik bagimu".

\section{Metode Adat dan Kebiasaan}

Lingkungan yang baik dan menyenangkan akan mempengaruhi keberhasilan seseorang, Apabila lingkungan sekolah dan orang tua memiliki satu pemahaman yang sama untuk memberikan lingkungan dan kebiasaan yang baik, maka akan memberikan pengaruh yang sangat baik. Ketika pendidikan menanamkan nilai-nilai tauhid, keimanan, kepatuhan kepada perintah Allah Swt. Maka anak itu akan menjadi anak yang patuh dan taat aturan. Adapun perintah Rasul Saw. jelas seperti dijelaskan dalam hadits Shahih, yaitu: "Setiap anak dilahirkan dalam keadaan fitrah (suci), maka kedua orang tuanyalah yang menjadikan mereka sebagai seorang Yahudi, Nasrani dan Majusi (HR. Bukhari).

\section{Metode Nasihat}

Pada tahapan ini, memberikan nasihat kepada anak-anak merupakan tanggung jawab orang tua maupun pendidik, karena nasihat akan memberikan efek yang paling baik, sehingga anak-anak mengetahui mana yang harus dilakukan dan mana yang harus ditinggalkan sesuai dengan prinsip-prinsip agama dan prinsip penciptaan manusia. AlQur'an penuh dengan ayat-ayat yang menjadikan metode nasihat (memberikan pengajaran) sebagai sarana seruan dan ajakan kepada kebaikan. Seperti nasihat Lukman kepada anaknya yang diabadikan dalam Surat Luqman ayat 13, yaitu: "Dan (ingatlah) ketika Luqman berkata kepada anaknya, di waktu ia memberikan pelajannya kepadanya. Hai anakku, janganlah kamu mempersekutukan Allah...(QS. 31: 13). 


\section{Metode Perhatian}

Maksud dari metode ini adalah memberikan dan mencurahkan segala perhatian dan senantiasa mengikuti terus perkembangan anak dalam pembinaan akhlak. Di era modern ini banyak orang tua merasa cukup senang ketika anaknya diam di rumah dengan asyik di dunianya terutama bemain handphone. Sementara saat ini banyak pengaruh negatif dari handphone tersebut anak dapat mengakses semua informasi. Di sini peran perhatian sangat penting bagi perkembangan anak. Ali r.a, menfasirkan, "kụ anfusakum", di surat At-Thahrim ayat 6, dengan arti didiklah dan ajarilah mereka. Umar r.a. menafsirkan melarang mereka sesuai yang dilarang Allah, yaitu orang tua dan pendidik harus mampu memberikan perhatian akan nilai-nilai agama dan moral, yaitu menjaga anak-anak dari siksa api neraka. Dalam Surat Thaha ayat 132 dijelaskan: "Dan perintahkan kepada keluargamu mendirikan shalat dan bersabarlah kamu dalam mengajarkannya (QS. 20:132).

\section{Metode Hukuman}

Dalam hal ini memberikan batasan bahwa ketika melakukan pelanggaran ada konsekuensi hukuman. Ini membuktikan adanya kedisiplinan dalam memberikan pendidikan kepada anak-anak. Hukuman di sini merupakan proses pembentukan karakter dan akhlak anak sesuai dengan nilai-nilai agama dan moral. Karena agama sendiri memiliki arti, "a" tidak dan "gama" kacau (bahasa sansakerta). Hukuman merupakan proses menjaga agama, menjaga jiwa, menjaga kehormatan, menjaga akal dan menjaga harta. Dijelaskan dalam Hadits Rasulullah Saw. "Perintahkan anak-anakmu shalat ketika mereka berumur 7 tahun, dan pukullah (bila meninggalkan shalat) ketika berumur 10 tahun" (HR. Abu Daud, At Thirmidzi). Ini bukti ketika mendidik anak-anak harus benar-benar mengikuti perintah agama.

\section{Kesimpulan}

Dari Uraian di atas, maka dapat disimpulkan bahwa perlunya pola pendidikan nilai-nilai agama dan moral menjadi perhatian dari semua pihak, baik orang tua, guru dan lingkungan masyarakat menjadi satu kesatuan untuk menjadikan anak-anak yang kuat dengan menanamkan pondasi agama dalam proses perkembangan mulai sejak dini hingga dewasa. Mengembangkan metodemetode yang bervariasi, komunikatif, sesuai dengan perkembangan anak dan kemajuan zaman. Sehingga metode pembelajaran itu menarik dan mudah diterima oleh anak-anak.

\section{Daftar Pustaka}

Al-Qur'an dan Terjemahnnya. (2008). Departemen Agama RI. Bandung: CV Diponogoro.

Said bin Ali bin Wahf Al Qhathani. (2015). Panduan Lengkap Tarbiyatul Aulad. Solo: Zam-Zam.

Abdulah Ali. (2016). Panduan Shalat Lengkap sesuai Tuntunan Rasulullah Saw. Yogyakarta: Bintang Pustaka

Abdullah Nasih Ulwan. (1986). Pedoman Pendidkan Anak Dalam Islam. Bandung: Asy-Syifa

https://www.paud.id "Pedoman Kurikulum 2013. Jakarta. 2016

Hamalik Oemar. (2000). Psikologi Belajar dan Mengajar. Bandung: Sinar Baru Algesindo. 